\title{
IT Governance in Enterprise Resource Planning and Business Intelligence Systems Environment: a Conceptual Framework
}

\author{
Carlo Caserio
}

\author{
Assist. Prof. in Business Economics, Università degli Studi eCampus, Novedrate, Como, Italy
}

carlo.caserio@uniecampus.it

\begin{abstract}
A large number of studies has been carried out on IT governance during the last decade, with the aim to support companies in implementing IT governance frameworks aligned with the business strategy. However, companies which create value and develop competitive advantage through an intensive use of Enterprise Resource Planning (ERP) and Business Intelligence Systems (BIS), should implement an IT governance framework tailored on Critical Success Factors (CSFs) of both systems. To organise the main studies on IT governance frameworks, as well as to support companies in designing (or reviewing) their IT governance framework by considering the CSFs of ERP and BIS, a conceptual framework is introduced and discussed. The insights arising from this study are supported by the literature and suggest that an IT governance framework should be designed by considering the ERP and BIS critical success factors, especially in companies whose success heavily depends on such systems.
\end{abstract}

\section{Indexing terms/Keywords}

IT Governance Framework, Enterprise Resource Planning (ERP), Business Intelligence Systems (BIS), Critical Success Factors

\section{INTRODUCTION}

IT governance is one of the most important factors that allows companies to generate business value from IT investments [1]. Major literature on IT governance shows definitions expressed under different perspectives, as the IT governance has several determinants, such as business strategy, business governance, firm size, information-intensity, environment stability, business competency [2].

These definitions arise from the shared acknowledgment that the notion of a single homogeneous IT function is now obsolete [3] as the IT is widely distributed in organizations and requires a holistic definition that includes actors, responsibilities, decision-making process and activities related to IT.

On the basis of such a holistic vision, many authors define IT governance as the pattern and the locus of authority for key IT activities [4], [5], [6]. Other studies define IT governance as the locus of responsibility for IT functions [7], [8] and still others attribute more emphasis to the role of top management. For example, IT Governance Institute considers IT governance as the responsibility of the board of directors and executive management in ensuring the alignment between organization's strategy and IT resources [9]. A similar point of view is expressed by other scholars, who state that IT governance is the organizational capacity of board, executive management and IT management to control the design and the implementation of IT strategy, ensuring the fusion of business and IT [10]. IT governance is also defined as the specification of decision rights and accountability framework aimed at encouraging desirable behaviours when IT is used [1].

From the above general definitions, it is possible to understand that all the issues involved in IT governance are relevant for the successful management of IT resources, activities, functions and decision-making processes. Given the importance of IT governance in the success of IT investments, several frameworks have been proposed by the academic and nonacademic literature.

In the second section of this paper, a literature analysis on the main IT frameworks is proposed, with the aim to identify the main recommendations of scholars for correctly implementing the IT governance inside companies.

In the third section such recommendations are examined in the light of the Critical Success Factors (CSFs) of Enterprise Resource Planning (ERP) and Business Intelligence Systems (BIS) and of the linkages between them. Literature on the relationships between IT governance, ERP and Business Intelligence Systems (BIS) investments is fairly scarce, as only a few studies analyse the role of IT governance framework in the ERP context [11], [12]. For these reason, the present study aims to fill this research gap providing a combined vision of IT governance framework, ERP and BI systems.

In the fourth section of this paper, a conceptual framework is proposed, to introduce a possible procedure that would be helpful to design an IT governance framework in an ERP and BIS environment.

\section{LITERATURE REVIEW}

Weill and Ross [1], through a governance arrangement matrix, identify the possible IT governance archetypes used for different types of decisions and, on this basis, define an IT governance framework useful for managers to understand how to align their strategy, IT governance and performance between each other. Brown and Grant [13] propose a conceptual framework for IT governance research, which recognizes the two different perspectives of analysis followed by prior researches on IT governance: 1) IT governance forms and 2) IT governance contingency analysis. The first category 

refers mainly to the studies focused on the locus of IT decision-making process, which could be centralized [14], [15] - i.e. performed by an internal Information System (IS) body and considered suitable for the control over the IT standards and for the achievement of economies of scale - or decentralized - i.e. distributed among the business units and considered more useful for responding to specific business needs [16], [17], [18]. The second perspective of analysis includes researches that try to understand which IT governance framework best fits which company, grounding the studies on the contingency theory. The present study belongs to the second stream, as it proposes an IT governance framework based on specific company's contingencies, that consist in the intensive utilization of ERP and BI systems.

Other authors, recognizing that IT governance is a multidimensional concept, apply the balanced scorecard to the IT and identify four dimensions, strictly interrelated between each other: IT value, user, operational excellence, future orientation [19], [20], [21].

In support to the IT governance framework design, another study is proposed by DeLone and McLean in 1992 [22] and up to dated in 2003 [23]. The authors propose an Information Systems (IS) Success Model based on six dimensions: system quality, information quality, use, user satisfaction, individual impact, organizational impact. The DeLone and McLean's model is not actually an IT governance framework, as it represents an attempt to organize the literature on the quality of IS, but it can still be useful for top managers who aim to identify the quality "drivers" of their Information System and to recognize possible IS anomalies to be fixed.

The usefulness of IS Success Model is also confirmed by researches which combine it with other IT frameworks, such as Cobit (Control Objectives for Information and related Technology), to analyse the Information Systems implementation process [24]. About Cobit, other studies show its potentialities for managers who aim to develop an effective internal control over financial reporting [25] and for IT auditors [26], [27]. Cobit framework plays an important role for IT governance, as it provides the best practices on how to plan and organize the IT function inside the company, how to acquire the most suitable IT solutions, how to deliver the IT services and how to monitor and assess the IT system performance [26]. Main principles of Cobit are the alignment between business goals and IT goals, an effective and responsible use of IT resources and an appropriate management of IT-related risks [28], [29]. The holistic vision provided by Cobit on the IT function and the causal links between the Cobit dimensions, led scholars to combine Cobit framework with Balanced Scorecard, in order to implement an appropriate Service Level Management process [30]. ITIL framework, in addition to Cobit, includes a set of best practices aimed at supporting IT governance in aligning business needs with IT services [31] and, despite it presents some differences compared with Cobit [32], the two frameworks have substantially the same objective.

The major shared opinions emerging from the literature analysis on the IT governance frameworks are the followings: 1) IT governance is a senior management responsibility; 2) the alignment of business strategy and IT resources is one of the most important goals and critical success factor for IT governance effectiveness.

About the first point, Weill and Ross [1] proposes a set of principles for leaders who aim to implement an effective IT governance: a) the leadership has to be involved in the project and has to define an appropriate timing in designing IT governance; b) it is important to highlight eventual conflicting goals and debate about them; c) procedures have to be defined on how to manage exceptions; d) the incentive and reward systems have to be aligned; e) it is necessary to assign ownership and responsibilities for IT governance; f) IT governance has to be defined considering the multiple organization levels; g) transparency and education have to be provided; h) all the key assets have to be managed according to the same mechanisms.

With regard to point 2), a literature stream deals specifically with strategic alignment models in an IT environment [6], [33], [34]. In this regard, Luftman and Brier [35], on the base of a survey, identify the enablers and inhibitors factors of ITbusiness alignment and propose a framework composed of twelve items belonging to four different alignment perspectives: business strategy, organizational infrastructure and processes, IT strategy, IT infrastructure and processes.

Despite the existence of several prior frameworks aiming to support companies in the development of competitive advantage from their IT investments, IT projects failures continue to happen and the attention paid by scholars on the ITproject failures has not decreased along the time. In fact, several researches recently examined the reasons underlying the IT project failures [36], [37], [38] that can probably be due to resistance to change [39], to an erratic adoption of IT frameworks, or to the impossibility to thoroughly follow the framework, given the complexity of the internal and external environment in which the company operates. Furthermore, managers could be unable to realize the potential of an IT investment and, according to Dos Santos and Sussman [40], new IT investments could be even perceived as a threat by managers, as these investments affect their sense of control and competence. These critical issues highlight the relevant role of IT governance, which should allow IT projects to be accurately followed, from the implementation to the postimplementation phase, ensuring the continuous coherence between business and organizational needs, IT resources and competencies. Thus, IT governance frameworks could play a very important role in avoiding the failure of IT projects and in managing the risks related to the implementation and post-implementation phases. The hypothesis underlying this research, evidently supported by the contingency theory, is that companies which rely on ERP and BI systems for supporting their decision-making process and developing competitive advantage, should design their IT governance framework on the base of the CSFs of ERP and BI systems. 
International Journal of Management and Information Technology METHOD

The first step of this research is the review of the main literature on the IT governance, conducted to collect the main recommendations posited by the major IT governance frameworks, and to obtain a comprehensive vision of the topic (Table 1).

The second step is to lay down the main ERP and BIS critical success factors (Table 2), which are very important for the successful implementation of IT governance framework, especially when the competitive advantage depends in large part on these systems.

The third step is to propose a conceptual framework which helps managers to combine the IT governance recommendations with the critical success factors of ERP and BIS.

Table 1 - Main IT Governance Frameworks

\begin{tabular}{|c|c|c|c|c|}
\hline $\begin{array}{l}\text { Weill and Ross } \\
\text { (2004b) }\end{array}$ & $\begin{array}{c}\text { Van Grembergen } \\
(2005)\end{array}$ & $\begin{array}{l}\text { De Lone and McLean } \\
\text { (1992) }\end{array}$ & $\begin{array}{l}\text { Luftman and } \\
\text { Brier (1999) }\end{array}$ & $\begin{array}{c}\text { Cobit } \\
\text { (ITGI, 2011) }\end{array}$ \\
\hline $\begin{array}{l}\text { Framework based } \\
\text { on four steps: } \\
\text { 1) Identify } \\
\text { company's } \\
\text { needs for } \\
\text { synergy and } \\
\text { autonomy } \\
\text { 2) Establish the } \\
\text { role of } \\
\text { organization } \\
\text { structure } \\
\text { 3) Identify the } \\
\text { desirable IT- } \\
\text { related } \\
\text { behaviours } \\
\text { falling outside } \\
\text { the scope of } \\
\text { organizational } \\
\text { structures } \\
\text { Design IT } \\
\text { governance on } \\
\text { one page }\end{array}$ & $\begin{array}{l}\text { IT Scorecard } \\
\text { Framework: } \\
\text { 1) IT value } \\
\text { 2) User } \\
\text { 3) Operational } \\
\text { excellence } \\
\text { 4) Future } \\
\text { orientation }\end{array}$ & $\begin{array}{l}\text { IS Quality Framework: } \\
\text { 1) System quality } \\
\text { 2) Information quality } \\
\text { 3) Use } \\
\text { 4) User satisfaction } \\
\text { 5) Individual impact } \\
\text { 6) Organizational } \\
\text { impact }\end{array}$ & $\begin{array}{l}\text { Strategic } \\
\text { Alignment } \\
\text { Framework: } \\
\text { 1) Business } \\
\text { strategy } \\
\text { 2) Organization } \\
\text { al } \\
\text { infrastructur } \\
\text { e and } \\
\text { processes } \\
\text { 3) IT strategy } \\
\text { 4) IT } \\
\text { infrastructur } \\
\text { e and } \\
\text { processes }\end{array}$ & $\begin{array}{l}\text { Cobit Framework } \\
\text { ensures that: } \\
\text { 1) IT is aligned with } \\
\text { the business } \\
\text { 2) IT enables the } \\
\text { business and } \\
\text { maximises } \\
\text { benefits } \\
\text { 3) IT resources are } \\
\text { used responsibly } \\
\text { 4) IT risks are } \\
\text { managed } \\
\text { appropriately } \\
\text { Performance } \\
\text { measurement is } \\
\text { adopted to } \\
\text { monitor the } \\
\text { strategy } \\
\text { implementation. }\end{array}$ \\
\hline
\end{tabular}

The implementation of an IT governance framework in an ERP and BIS context, necessarily requires to consider the peculiarities and the CSFs of such systems, so that IT governance framework could be adapted to the ERP and BI systems' characteristics. About ERP systems, prior literature has paid much attention to the ERP implementation and to the related CSFs [41], [42], [43], however, more recently, literature is taking into consideration the role of maintenance in keeping ERP effective along the time [12], [44], [45], [46] and is examining the CSFs of the entire ERP life-cycle [47], [48], [49]. Critical success factors of ERP are shown in Table 2 (first column) and refers to the study of Finney and Corbett (2007) [47]. ERP maintenance has been included among the main ERP CSFs as suggested by Law et al. [11].

Regarding CSFs of $\mathrm{BI}$ systems, literature is more recent and less ample than that on CSFs of ERP, but it still provides many studies which aim to determine CSFs of BI systems. Taking into account the main researches on this topic, it is possible to identify the most frequent CSFs emerging from the literature. Several researches propose set of CSFS of BIS [50], [51], [52], [53], [54] with the common aim to categorise the conditions that improve the business performance, increase the profitability of $\mathrm{BI}$ investments and support the decision-making process. Table 2 (second column) shows the set proposed by Yeoh and Koronios [50], whereas testing, project scope and interaction with SAP are critical success factors suggested by Hawking and Sellitto [51], who find out that the interaction with the ERP is one of the CSFS of BIS

Table 2 - Main Critical Success Factors of ERP and BI Systems

\begin{tabular}{|l|l|}
\hline \multicolumn{1}{|c|}{ Critical Success Factors of ERP Systems } & \multicolumn{1}{c|}{ Critical Success Factors of BI Systems } \\
\hline Leadership involvement & Committed management support and sponsorship \\
\hline Change management & Clear vision and well-established business case \\
\hline
\end{tabular}


International Journal of Management and Information Technology

\begin{tabular}{|l|l|}
\hline Business Process Reengineering & $\begin{array}{l}\text { Business-centric championship and balanced team } \\
\text { composition }\end{array}$ \\
\hline Training & Business-driven and iterative development approach \\
\hline Project team & User-oriented change management \\
\hline Implementation strategy & $\begin{array}{l}\text { Business-driven, scalable and flexible technical } \\
\text { framework }\end{array}$ \\
\hline Selection of consultants & Sustainable data quality and integrity \\
\hline Vision and business plan & Testing \\
\hline Balanced team & Interaction with SAP \\
\hline Project champion & ERP quality \\
\hline Communication & Testing \\
\hline Maintenance & Project scope \\
\hline
\end{tabular}

Other studies propose CSFs of BIS under different perspectives, such as Olszak and Ziemba [55], who deal with CSFs of BIS in small-medium enterprises, Lloyd [56], who examines the impact of CSFs on managerial decision making, Dawson and Van Belle [57], who analyse CSFs of BIS in financial services sector. Even the ERP effectiveness and maintenance could be included among the critical success factors of BIS, as the quality of transactional data - which are the input of BIS - affects unavoidably the quality of BIS output. This is confirmed by Hawking and Sellitto [51] who include Data Quality among the CSFs of $\mathrm{BI}$ systems and it is also confirmed by the literature on the integration between ERP and $\mathrm{BI}$ systems, which underlines that such an integration positively affects decision-making performance, timeliness of data access, data management and decision capability [58], [59]. Literature on the role of data quality for decision-making process [60], [61], [62] provides a further confirmation. In the light of these considerations, the critical success factor "ERP quality" has been included in Table 2 (second column) among the CSFs of BIS, as it represents the effectiveness of the ERP to provide reliable data to the decision maker and the appropriateness of ERP maintenance.

\section{DISCUSSION}

Literature shows several causes of IT projects failures, mainly related to the management, such as unrealistic expectations, excessive perception of flexibility in budget and time, overambitious projects, related to the environment in which the company operates (i.e. hidden complexity, uncertainty), and related to technical aspects, such as software failure and poor knowledge of business processes by IT practitioners [38], [63], [64]. Several studies identify the Critical Failure Factors (CFFs) of projects such as ERP implementation [65], [66], [67] and Business Intelligence Systems development, both in the specific EIS (Executive Information Systems) field [68], [69] and in the more general area of Information System projects [70], [71].

Studies on IT governance focus the attention on the strategic role of actors, roles and responsibilities involved in the governance of IT resources. IT governance, thus, refers to all the IT-related resources of a company and thus it is plausible that the more challenging is the implementation and post-implementation of an IT project, the more critical becomes a good IT governance for the success of the project. Recent literature recognizes, as challenging IT projects, the implementation of ERP and BIS, which requires great efforts from companies and may produce serious problems in case of project failure [72], [73], [74]. As a consequence, the capacity to follow the recommendations of IT governance frameworks is crucial for a successful implementation and post-implementation of expensive and impactful projects such as ERP and BI systems. Furthermore, ERP and BIS have critical success factors that should be considered in the choice of an IT governance framework. Therefore, as shown in Fig. 1, IT governance frameworks should be considered as guides for ERP and BIS implementation, as they provide the general principles to follow and the strategic objectives to pursue.

Benefits of IT governance frameworks for ERP and BIS implementation and post-implementation would be obtained by taking advantage of the recommendations that best suit the needs of the business strategy and by adapting such recommendations to the critical success factors of ERP and BIS.

As an example, it would be useful to follow the framework of Weill and Ross [75] and/or DeLone and McLean [22] to compare the Information Systems (IS) quality expectations with the actual IS quality characteristics and to identify company's needs about ERP and BIS; afterwards, the framework of Van Grembergen [20] would be used to identify the causal links between the IT dimensions, that is the ERP and BIS characteristics and CSFs; the Luftman and Brier [35] framework, along with the Cobit [29], could help to correctly align ERP and BIS CSFs with the business strategy. The final result of such a process would be an IT governance framework tailored on the critical success factors of ERP and BIS, and thus, an IT governance framework which would be more effective for managing an ERP- and BIS-based Information System. 

Literature confirms the capacity of IT governance frameworks to provide a series of useful recommendations and approaches which allow a holistic vision of the strategy and an effective and efficient adoption of IT resources [76]. Moreover, a prior empirical research on the relationship between IT governance and ERP systems, conducted through a survey, shows that ERP investments are more successful when IT governance is based on a proactive strategic guidance [12]. This means that the ERP success is a cause of "good" IT governance.

Fig. 1 - A Conceptual Framework for Designing IT Governance Framework in ERP and BIS Environments

\begin{tabular}{|c|c|c|c|c|}
\hline \multicolumn{5}{|c|}{ IT Governance Frameworks } \\
\hline $\begin{array}{c}\text { Weill and Ross } \\
\text { (2004b) }\end{array}$ & Van Grembergen & DeLone and McLean & Luftman and Brier & Cobit \\
(2003) & $(1992)$ & (1999) & (ITGI, 2011) \\
\hline
\end{tabular}

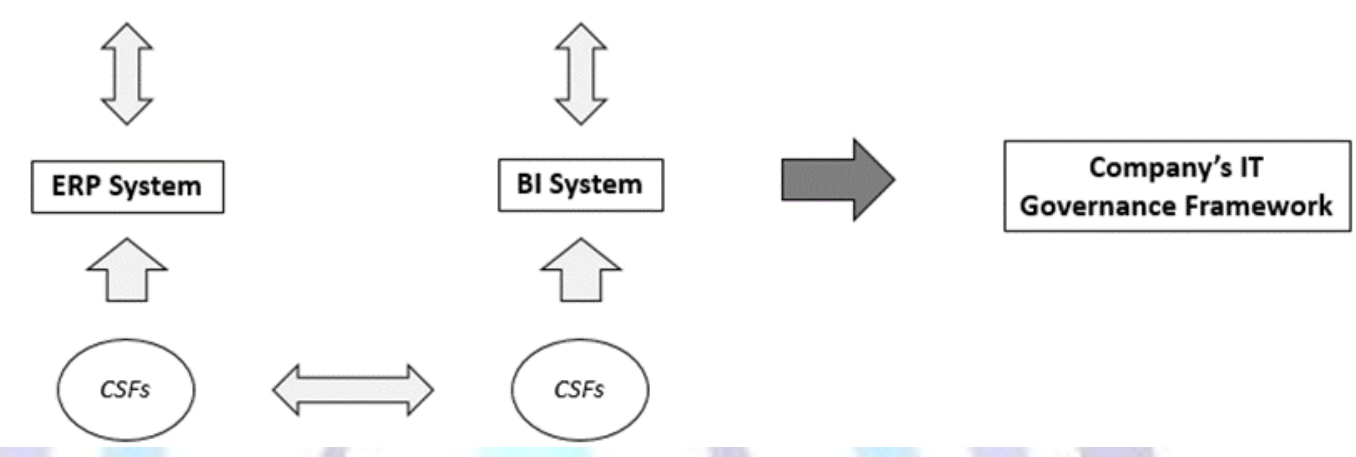

The idea of this research is that such a "good" IT governance could be planned in advance, by aligning the IT governance framework with the business strategy and by considering the CSFs of ERP and BI systems during the design of the framework. In this view, top managers aim to plan in advance the association between ERP and BIS success and IT governance framework success.

\section{CONCLUSIONS, LIMITATIONS AND FUTURE RESEARCHES}

IT governance frameworks are thought to help companies in organizing the responsibilities for the IT resources and the locus of authority for critical IT activities. Such frameworks aim to support companies in generating business value from IT investments, especially when the IT resources are critical for the business success.

The information era we are living, the hypercompetition and the globalization have increased the need of companies to invest in IT capacities. Nowadays, companies of any size use integrated systems such as ERP (for larger companies) or light ERP (for small-medium sized companies) to better manage the transactional business data. Consequently, also the $\mathrm{BI}$ systems have spread considerably, as they allow companies to elaborate business data to acquire the knowledge they need for gaining a competitive advantage and a support to their decision-making processes.

The contribution to the literature, provided with this research, consists in an organisation of the main IT governance frameworks, and in the proposal of a conceptual framework, grounded on the contingency theory, which helps companies characterized by an intensive use of ERP and BI systems, to design a successful IT governance framework. The study is based on the following conceptual points: a) every IT governance framework supported by the literature provides insights and recommendations which could help companies in defining their own framework; $b$ ) in companies that largely invest in $\mathrm{ERP}$ and $\mathrm{BI}$ systems and whose value creation mainly depends on these systems, such recommendations should be adapted to the critical success factors of ERP and BI systems; c) consequently, because the IT governance framework is designed taking into consideration the CSFs of ERP and BIS, it will be more effective.

The main implication of this study is the provision of a comprehensive view of IT governance frameworks and of ERP and BIS critical success factors. Managers could receive support from the conceptual framework proposed in this research, as it provides a process which organises the elements to be assessed in the design (or in the review) of an IT governance framework in an ERP and BIS environment. Moreover, this study provides a taxonomy of the main CSFS of ERP and BIS and insights on the relationships between the two systems.

The main limitation of this research is that the conceptual framework, although it is strongly based on the literature, proposes a theoretical process which would need empirical evidence. Hence, the present study can be seen as a starting point for future empirical researches aimed to investigate the real validity of the framework proposed.

\section{REFERENCES}

1) Weill, P., \& Ross, J. W. (2004a). IT governance: How top performers manage IT decision rights for superior results. Harvard Business Press. 
International Journal of Management and Information Technology

2) Peterson, R. (2004). Crafting information technology governance. Information Systems Management, 21(4), 7-22.

3) Van Grembergen, W., De Haes, S., \& Guldentops, E. (2004). Structures, processes and relational mechanisms for IT governance. Strategies for information technology governance, 2(4), 1-36.

4) Sambamurthy, V., \& Zmud, R. W. (1999). Arrangements for information technology governance: A theory of multiple contingencies. MIS quarterly, 23(2), 261-290.

5) Sambamurthy, V., \& Zmud, R. W. (2000). Research commentary: The organizing logic for an enterprise's IT activities in the digital era-A prognosis of practice and a call for research. Information systems research, 11(2), 105-114.

6) Luftman, J. (1996). Competing in the Information Age: Practical applications of the strategic alignment model, New York: Oxford University Press.

7) Brown, C. V., \& Magill, S. L. (1994). Alignment of the IS functions with the enterprise: toward a model of antecedents. Mis Quarterly, 18(4), 371-403.

8) Boynton, A. C., Jacobs, G. C., \& Zmud, R. W. (1992). Whose responsibility is IT management?. MIT Sloan Management Review, 33(4), 32-38.

9) ITGI, I. Governance Institute, \& ITGI. (2001). Board briefing on IT governance.

10) Van Grembergen, W. (Ed.). (2004). Strategies for information technology governance. Igi Global.

11) Law, C. C., Chen, C. C., \& Wu, B. J. (2010). Managing the full ERP life-cycle: Considerations of maintenance and support requirements and IT governance practice as integral elements of the formula for successful ERP adoption. Computers in Industry, 61(3), 297-308.

12) Bernroider, E. W. (2008). IT governance for enterprise resource planning supported by the DeLoneMcLean model of information systems success. Information \& Management, 45(5), 257-269.

13) Brown, A. E., \& Grant, G. G. (2005). Framing the frameworks: A review of IT governance research. Communications of the Association for Information Systems, 15(1), Article 38, 696-712.

14) Boynton, A. C., \& Zmud, R. W. (1987). Information technology planning in the 1990's: directions for practice and research. MIS quarterly, 11(1), 59-71.

15) Schwarz, A., \& Hirschheim, R. (2003). An extended platform logic perspective of IT governance: managing perceptions and activities of IT. The journal of strategic information systems, 12(2), 129-166.

16) Luo, Y., \& Bu, J. (2016). How valuable is information and communication technology? A study of emerging economy enterprises. Journal of World Business, 51(2), 200-211.

17) Von Simson, E. M. (1995). The recentralization of IT. Computerworld, 29(51), 1-5.

18) Keen, P. G. (1981). Communications in the 21st century: Telecommunications and business policy. Organizational Dynamics, 10(2), 54-67.

19) Van Grembergen, W. (2000, May). The balanced scorecard and IT governance. In IRMA Conference (pp. 1123-1124).

20) Van Grembergen, W., \& De Haes, S. (2005). Measuring and improving IT governance through the balanced scorecard. Information Systems Control Journal, 2(1), 35-42.

21) Symons, C. (2005). IT governance framework. Forrester Research.

22) DeLone, W. H., \& McLean, E. R. (1992). Information systems success: The quest for the dependent variable. Information systems research, 3(1), 60-95.

23) DeLone, W. H., \& McLean, E. R. (2003). The DeLone and McLean model of information systems success: a ten-year update. Journal of management information systems, 19(4), 9-30.

24) Muliadi Kerta, J. and Suryawan A. D. (2013). Analysis of information system implementation in Binus University using DeLone and McLean Information System Success Model and Cobit framework. International Journal of Communication \& Information Technology, 7(01), 13-17. 
International Journal of Management and Information Technology

25) Kerr, D. S., \& Murthy, U. S. (2013). The importance of the CobiT framework IT processes for effective internal control over financial reporting in organizations: An international survey. Information \& Management, 50(7), 590-597.

26) Lainhart IV, J. W. (2000). COBIT тм: A methodology for managing and controlling information and information technology risks and vulnerabilities. Journal of Information Systems, 14(s-1), 21-25.

27) Moeller, R. R. (2010). IT audit, control, and security (Vol. 13). John Wiley \& Sons.

28) Bakry, S. H., \& Alfantookh, A. (2006). IT-governance practices: COBIT.

29) ITGI (2011). CObIT 4.1 (2007). IT Governance Institute, Rolling Meadows, IL, USA.

30) Van Grembergen, W., De Haes, S., \& Amelinckx, I. (2003). Using COBIT and the balanced scorecard as instruments for service level management. Information Systems Control Journal, 4, 56-62.

31) Iden, J., \& Eikebrokk, T. R. (2014). Using the ITIL process reference model for realizing IT Governance: An empirical investigation. Information Systems Management, 31(1), 37-58.

32) Sahibudin, S., Sharifi, M., \& Ayat, M. (2008, May). Combining ITIL, COBIT and ISO/IEC 27002 in order to design a comprehensive IT framework in organizations. In Modeling \& Simulation, 2008. AICMS 08. Second Asia International Conference on (pp. 749-753). IEEE.

33) Henderson, J. C., \& Venkatraman, N. (1992). Strategic alignment: a model for organizational transformation through information technology. Transforming organizations, 97-117.

34) Luftman, J. N., Ben-Zvi, T., Dwivedi, R., \& Rigoni, E. H. (2012). IT Governance: An alignment maturity perspective. Business Strategy and Applications in Enterprise IT Governance, 87-101.

35) Luftman, J., \& Brier, T. (1999). Achieving and sustaining business-IT alignment. California management review, 42(1), 109-122.

36) Hughes, D. L., Dwivedi, Y. K., Simintiras, A. C., \& Rana, N. P. (2015). Success and failure of IS/IT projects: A state of the art analysis and future directions. Springer.

37) Stoica, R., \& Brouse, P. (2013). IT project Failure: A proposed four-phased adaptive multi-method approach. Procedia Computer Science, 16, 728-736.

38) Al-Ahmad, W., Al-Fagih, K., Khanfar, K., Alsamara, K., Abuleil, S., \& Abu-Salem, H. (2009). A taxonomy of an IT project failure: root causes. International Management Review, 5(1), 93-104.

39) Kim, H. W., \& Kankanhalli, A. (2009). Investigating user resistance to information systems implementation: A status quo bias perspective. MIS quarterly, 567-582.

40) Dos Santos, B., \& Sussman, L. (2000). Improving the return on IT investment: the productivity paradox. International journal of information management, 20(6), 429-440.

41) Davenport, T. H. (1998). Putting the enterprise into the enterprise system. Harvard business review, 76(4).

42) Fui-Hoon Nah, F., Lee-Shang Lau, J., \& Kuang, J. (2001). Critical factors for successful implementation of enterprise systems. Business process management journal, 7(3), 285-296.

43) Somers, T. M., \& Nelson, K. G. (2004). A taxonomy of players and activities across the ERP project life cycle. Information \& Management, 41(3), 257-278.

44) Nah, F. F. H., \& Delgado, S. (2006). Critical success factors for enterprise resource planning implementation and upgrade. Journal of Computer Information Systems, 46(5), 99-113.

45) Caserio, C. (2011). Relationships between ERP and Business Intelligence: An empirical research on two different upgrade approaches. In Information Technology and Innovation Trends in Organizations (pp. 363-370). Physica-Verlag HD.

46) Wang, Y., Greasley, A., \& Albores, P. (2016). Do manufacturing firms need informality in ERP postimplementation? A study of Chinese manufacturing sites. Journal of Manufacturing Technology Management, 27(1), 100-123.

47) Finney, S., \& Corbett, M. (2007). ERP implementation: a compilation and analysis of critical success factors. Business Process Management Journal, 13(3), 329-347. 
International Journal of Management and Information Technology

48) Alsulami, M., Scheepers, H., \& Rahim, M. M. (2016, January). A Comparison between Organizational Stakeholders' and External Consultants' Perceptions on CSFs Affecting ERP Life Cycle Phases. In System Sciences (HICSS), 2016 49th Hawaii International Conference on (pp. 4676-4685). IEEE.

49) Li, H. J., Chang, S. I., \& Yen, D. C. (2017). Investigating CSFs for the life cycle of ERP system from the perspective of IT governance. Computer Standards \& Interfaces, 50, 269-279.

50) Yeoh, W., \& Koronios, A. (2010). Critical success factors for business intelligence systems. Journal of computer information systems, 50(3), 23-32.

51) Hawking, P., \& Sellitto, C. (2010, December). Business Intelligence (BI) critical success factors. In 21st Australian Conference on Information Systems (pp. 1-3).

52) Rud, O. P. (2009). Business intelligence success factors: tools for aligning your business in the global economy (Vol. 18). John Wiley \& Sons.

53) Woodside, J. (2011, April). Business Intelligence Best Practices for Success. In International Conference on Information Management and Evaluation (p. 556). Academic Conferences International Limited.

54) Sangar, A. B., \& lahad, N. B. A. (2013). Critical factors that affect the success of business intelligence systems (BIS) implementation in an organization. Intelligence, 12, 14-16.

55) Olszak, C. M., \& Ziemba, E. (2012). Critical success factors for implementing business intelligence systems in small and medium enterprises on the example of upper Silesia, Poland. Interdisciplinary Journal of Information, Knowledge, and Management, 7(2), 129-150.

56) Lloyd, J. (2011). Identifying key components of business intelligence systems and their role in managerial decision making (Doctoral dissertation, Intel Corporation).

57) Dawson, L., \& Van Belle, J. P. (2013). Critical success factors for business intelligence in the South African financial services sector: original research. South African Journal of Information Management, 15(1), 1-12.

58) Nofal, M. I., \& Yusof, Z. M. (2013). Integration of business intelligence and enterprise resource planning within organizations. Procedia Technology, 11, 658-665.

59) Agostino, R. (2002). Business intelligence: Solving the ERP overload crystal decisions. International Journal of Production Economics, 75(1-2), 315-353.

60) Shankaranarayanan, G., \& Cai, Y. (2006). Supporting data quality management in decision-making. Decision Support Systems, 42(1), 302-317.

61) Fisher, C. W., Chengalur-Smith, I., \& Ballou, D. P. (2003). The impact of experience and time on the use of data quality information in decision making. Information Systems Research, 14(2), 170-188.

62) Eckerson, W. W. (2002). Data quality and the bottom line: Achieving business success through a commitment to high quality data. The Data Warehousing Institute, 1-36.

63) Peffers, K., Gengler, C. E., \& Tuunanen, T. (2003). Extending critical success factors methodology to facilitate broadly participative information systems planning. Journal of Management Information Systems, 20(1), 51-85.

64) Salmeron, J. L., \& Herrero, I. (2005). An AHP-based methodology to rank critical success factors of executive information systems. Computer Standards \& Interfaces, 28(1), 1-12.

65) Umble, E. J., \& Umble, M. M. (2002). Avoiding ERP implementation failure. Industrial managementChicago then Atlanta, 25-33.

66) Tsai, W. H., Chien, S. W., Hsu, P. Y., \& Leu, J. D. (2005). Identification of critical failure factors in the implementation of enterprise resource planning (ERP) system in Taiwan's industries. International Journal of Management and Enterprise Development, 2(2), 219-239.

67) Al-Mashari, M., Al-Mudimigh, A., \& Zairi, M. (2003). Enterprise resource planning: A taxonomy of critical factors. European journal of operational research, 146(2), 352-364.

68) Poon, P., \& Wagner, C. (2001). Critical success factors revisited: success and failure cases of information systems for senior executives. Decision support systems, 30(4), 393-418. 
International Journal of Management and Information Technology

69) Arnott, D., \& Dodson, G. (2008). Decision support systems failure. In Handbook on Decision Support Systems 1 (pp. 763-790). Springer Berlin Heidelberg.

70) Yeoh, K. T. (2002). Critical failure factors in information system projects. International Journal of Project Management, 20(3), 241-246.

71) Lyytinen, K., \& Robey, D. (1999). Learning failure in information systems development. Information Systems Journal, 9(2), 85-101.

72) Zare Ravasan, A., \& Mansouri, T. (2016). A dynamic ERP critical failure factors modelling with FCM throughout project lifecycle phases. Production Planning \& Control, 27(2), 65-82.

73) Garg, P., \& Garg, A. (2013). An empirical study on critical failure factors for enterprise resource planning implementation in Indian retail sector. Business Process Management Journal, 19(3), 496-514.

74) Ko, I. S., \& Abdullaev, S. R. (2007, May). A study on the aspects of successful business intelligence system development. In International Conference on Computational Science (pp. 729-732). Springer Berlin Heidelberg.

75) Weill, P., \& Ross, J. W. (2004b). IT governance on one page. MIT Sloan Working Paper No. 4517-04; CIS Research Working Paper No. 349. Available at SSRN: https://ssrn.com/abstract=664612 or http://dx.doi.org/10.2139/ssrn.664612.

76) Hamaker, S., \& Hutton, A. (2004). Principles of IT governance. Information Systems Control Journal, 2 , 47-50.

\section{Authors' biography}

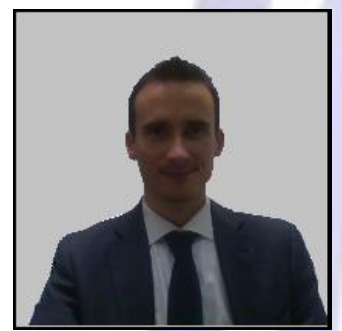

Carlo Caserio is an Assistant Professor of Business Economics at eCampus University, Novedrate, Como, Italy. He received his Ph.D. in Business Economics at the University of Macerata, Italy and he was a Research Fellow at the University of Pisa, Italy, where he conducted research activities on Management Information Systems and Management Control. $\mathrm{He}$ is a lecturer of Financial Accounting, Financial Statement Analysis and Management Control at the eCampus University, Faculty of Economics, and his research interests include the fields of Management Information Systems, Financial Accounting, Management Control and Accounting Information Systems. 